\title{
RESEARCH PAPER \\ SHOPPING MALLS AS CATALYST FOR SUB-URBAN DEVELOPMENT IN GHANA
}

\author{
V. K. Quagraine', R. A. Oppong ${ }^{2}$ and J. Agyekum-Sah ${ }^{3}$ \\ ${ }^{1 \& 2}$ Department of Architecture, College of Art and Built Environment, \\ KNUST, Kumasi, Ghana \\ ${ }^{3}$ KAAF University College, Buduburam, Ghana
}

\begin{abstract}
The concentration of population in major cities is usually the consequence of the concentration of employment opportunities, goods and services in such cities. These goods and services act as pull factors to the regional population, especially from the suburban or rural areas, to densely populated cities. The resulting migration creates congestion of all kinds in the cities. Suburban communities are, thus, rendered unattractive for living. This situation is prevalent in Ghana where $75 \%$ of migrants into major cities are from suburban areas and the rate of urbanization is 4.1\%. Decentralizing amenities to suburban areas would initiate re-distribution of population and thus development. This study investigated the possibility of using the Shopping Mall concept as catalyst to both help develop the suburbia and decongest cities in Ghana. The West Hills Mall at Dunkonah, a suburb near Accra was selected for the study. A mixed research method including questionnaires, interviews, and observations was used for data collection. Out of a total of 1,642 house owners 328 were sampled and interviewed with questionnaire that delved into their origins, whether they are migrants, and the reasons behind their movement. The study concluded that shopping malls could act as catalysts for development.
\end{abstract}

Keywords: Shopping Malls, Catalyst, Decongestion, Suburbanization, Amenities

\section{INTRODUCTION}

Congestion due to the concentration of human population and amenities, in major cities is considered a major issue, not only in Ghana but in the world at large (Poku-Boansi, 2014). The congestion phenomenon is as a result of unique or perceived opportunities offered to both the rich and the poor within cities. Such opportuni- ties, as discussed by Moore et al (2003) include education, retail, employment and other social services. These opportunities serve as both rural or suburban push and urban pull factors for migration into major cities in Ghana (Ghana Statistical Service, (GSS) 2005). Thus, about $75 \%$ of migrants into the major cities in Ghana come from suburban areas (Ackah and Medve- 


\section{Quagraine et al.}

dev, 2010). This phenomenon is also complimented by high rates of natural increase of the national population (Loeb and Luester, 2015). Urbanization in Ghana rose from $43.8 \%$ in 2000 to $50.9 \%$ in 2010 and at growth rate of $4.1 \%$. The urban population keeps on increasing in just a few very large urban centers in the country, especially in Accra (the capital of Ghana) and Kumasi, the country's second largest city due to the concentration of the mentioned opportunities in these areas.

Over $80 \%$ of national investment has been concentrated in Accra alone since 2008 (Azuliya, 2014). The resultant infrastructure and development form an undeniable attraction that pulls migrants to the city center. As a result of such developments, available infrastructure becomes overburdened, leading to proliferation of illicit activities such as squatting and displaying salable wares on pedestrian walkways (Farrag et al., 2010). Due to the concentration of most businesses in the city centres, a lot more individuals prefer to reside in close proximity to such areas in order to have easy and quick access to goods and services, resulting in congestion of all forms, including economic activities, vehicular traffic and overcrowding.

Congestion of people in the cities adversely affects productivity and costs of businesses. It was learnt from Boamah and Amoako (2013) that due to the road traffic congestion, many workers reported late to work but most of them left the workplaces early, in order to avoid the traffic congestion, to arrive home on time in the evening in addition to saving fuel. This would affect productivity negatively. Other workers, however, remained at their workplaces until very late in the night, as a means of avoiding the evening road traffic congestion and thus inconveniencing themselves and their families. Another study conducted by Takyi et al (2013) in Kumasi, Ghana, also revealed that on the average, people worked for nine hours and 34 minutes per day, but due to traffic congestion, 52 minutes and eight seconds are lost every day to the worker. Thus, on the average, the worker lost $9.4 \%$ of productive time every working day.

The urban opportunities that serve as pull factors for migrants also render the rural or suburban areas unattractive for living. As a consequence, the suburban communities are usually rendered unattractive for residence, whereas places close to the city centers become congested and highly populated (Squires and $\mathrm{Ku}-$ brin, 2006). Efforts are made by city authorities in Ghana to decongest the city through various means such as changing of traffic flow directions, towing of illegally parked vehicles, conversion of roads to one-way lanes, removal of street traders and installation of more traffic lights and street signs. The Department of Urban Roads, in March 2013, spent an amount of \$135million on the Accelerated Traffic Management System (ATMS), to manage the situation (Ghana Business News, 2017). However, nine months after that effort, the original situation of congestion came back in full force.

Several strategies have been employed to curb rural-urban migration, to decongest the city and also to develop suburban areas around the globe. These include Howard's (1902) Garden City concept that dwelled on town and country (suburban/urban) magnets and Thurston and Yezers' (1994) job suburbanization or relocation of jobs to the suburban areas to accelerate development. McGranahan's (1999) high level amenities concept which favors the development of high level amenities such as recreational and retirement facilities in unique areas (including coastlines areas and vicinities of lakes, mountains and forests) of suburban areas has also been used. The Central Place Theory (Christaller, 1966; Grove and Huszar, 1964 and Poku-Boansi, 2014) which is usually applied together with the decentralization of administration and governance to districts and local councils (Pares-Ramos et al., 2008) and the introduction of micro-credit schemes and expansion of rural banks to resource rural areas (GSS, 2005) have also been used to develop the suburbia especially in developing countries. 
However, this study concentrates on the use of shopping malls, which is a foreign phenomenon that has been used for various kinds of development, as catalysts to both develop the suburban areas and to decongest the urban areas.

\section{Shopping malls - A snapshot}

Globally, shopping malls emerged as stimulations to suburban development. Conceived originally as a community center for convergence of people, malls have become places for social interactions and cultural activities (Consumer Reports, 1986). They were also established in North America in the nineteenth century as 'out-of-town' business facilities to help decentralize retail and business activities from the cities. Thus, they were also used as a strategy to concentrate most businesses to the outskirts of cities in order to free the Central Business District (CBD) of the associated stress. Shopping malls have also evolved to become the center pieces for rejuvenation of run-down urban centres. Examples of these in the United States include the City-Center Indianapolis, Faneuil Hall - Boston, South Street Seaport - New York City, and Harbour Place, Baltimore. Many shopping malls in the USA have become attractions for tourists, and do offer interesting or appealing architectural features. Synergy is thereby created with the combination of activities such as retailing, eating and entertaining in these malls (Burger, 2014).

Egypt witnessed in the last few decades, as many Southeast Asian mega-cities had, the reshaping of public space through the creation of new shopping malls and recreation places. The creation of the shopping malls in Egypt went hand in hand with the 'gentrification' of certain areas of the city of Cairo (Abaza, 2011). They pulled 'recreational' consumers and offered the people suitable, cheap and convenient outing to break the monotony of daily activities (Farrag et al 2010). As a consequence, the country in 1980s and 1990s witnessed increasing prosperity among certain classes and the appropriation of new consumer lifestyles (Abaza, 2001) and thereby supporting the fact that the shopping mall is a catalyst for development.

Ligthelm (2008) emphasized that with an objective of providing people with diverse services and goods, shopping malls form a very essential element in the socio-economic development of communities within which they are located. Mall culture has become big business, as shopping malls have evolved into multistoried structures housing a large number of stores that sell diverse products and services (Irazabal and Chakravarty, 2007). Shopping Malls house a collection of entertainments, retail stores and restaurants, adjoined by pedestrian areas or exclusive pedestrian streets. It is asserted that entertainment is associated with important retail outcomes, such as impulse buying, time spent in stores, spending levels, and the willingness to visit a store again (De Nisco and Napolitano, 2006). Malls also serve as converging points for people to just "hang out" with friends and meet for business transactions (Mangleburg et al., 2004).

Heffner and Twardzik (2014) attest that modern shopping malls are becoming important centres of social life, serving for commercial, entertainment, recreational, cultural, educational, integration as well as socializing purposes. Shopping in malls is characterized by conviviality and convenience as they offer one-stop-shop experience to the customer. Items such as groceries, clothing and other fashion products, food, reading materials and cinemas are all available within the same location. A whole day can be spent at the mall to shop, dine, watch movies or even play games. They have become convenient meeting places for friends to "catch up", for families to do their weekly shopping, and also keep the children entertained. Shopping malls have developed gradually into remarkable centres of the universe (Consumer Reports, 1986). The conviviality and convenience associated with shopping in malls are also being experienced currently among the customers of the few shopping malls in Ghana (Anning-Dorson et al., 2013). 


\section{Shopping malls in Ghana}

The evolution of shopping malls in the country can be traced to the defunct shopping centres such as the United African Company (UAC), and the United Trading Company (UTC) both established during the colonial period and the Ghana National Trading Corporation (GNTC). These were all located in Accra. However, the development of modern shopping malls in Ghana is a recent phenomenon that is influencing and giving face-lift to communities within which they are situated. It began in 2000 with the refurbishment and expansion of the $A \& C$ retail center at East Legon, Accra into a shopping mall. From that time onwards, seven shopping malls have been added which are mostly situated in the urban areas in Accra with only two situated in its surrounding suburban areas. An eighth mall is under construction in Kumasi and when completed, it will be the largest in West Africa. Shopping malls provide the convenience of acquiring most goods and services within the same complex and locality in a single visit. Based on their use for various developments in both developed and developing countries (Consumer Reports, 1986; Abaza, 2001 and Burger, 2014), shopping malls in Ghana warrant scientific investigation to establish the possibility of being used as catalyst for the development of suburban communities.

The study area

Currently there are seven shopping malls oper- ating in Ghana and all of them are situated in Accra and its suburban areas. An eighth one is under construction in Kumasi. The West Hills Mall, the larger of the two suburban shopping malls in Ghana was selected for the study that investigated the potential of using shopping malls as catalysts for suburban development. Table 1 presents the eight malls in Ghana with the year in which operation began, the size of the facility, number of shops, town, city or village in which they are located and the type of settlement: urban or suburban in which they are situated.

The West Hills Mall, which covers an area of $27,500 \mathrm{~m}^{2}$ (Effah, 2014) is about 28.6 kilometres west of the CBD of Accra. Though it is currently the largest shopping mall in West Africa, it will become the second largest when the Kumasi City mall is completed. The Mall is situated in Dunkonah community found within the larger neighbourhood of the Ga South $\mathrm{Mu}$ nicipal Assembly. The Ga South Municipal Assembly shares a boundary with the Accra Metropolitan Assembly (AMA) to its east. It was created from the Ga West District Assembly in November 2007 with Weija as its capital (Ghana Statistical Service, 2014). The Mall's construction started in 2012 and it was commissioned for operation in 2014. It is named after the hills at the western part of the Greater Accra Region, where it is situated. Its location is closer to Kasoa in the Central Region than

Table 1: Shopping malls in Ghana

\begin{tabular}{lllllll}
\hline No. & Name & Year & Size & $\begin{array}{l}\text { No. of } \\
\text { shops }\end{array}$ & Location & $\begin{array}{l}\text { Type of } \\
\text { settlement }\end{array}$ \\
\hline 1 & A\&C Mall & 2000 & $6,000 \mathrm{~m}^{2}$ & 30 & Accra & Urban \\
2 & Accra Mall & 2007 & $25,500 \mathrm{~m}^{2}$ & 65 & Accra & Urban \\
3 & Marina Mall & 2013 & $12,250 \mathrm{~m}^{2}$ & 45 & Accra: Airport city & Urban \\
4 & Junction Mall & 2014 & $11,597 \mathrm{~m}^{2}$ & 52 & Nungua: near Accra & Suburban \\
5 & Oxford Street Mall & 2014 & $6,230 \mathrm{~m}^{2}$ & 27 & Accra & Urban \\
6 & West Hills Mall & 2014 & $27,500 \mathrm{~m}^{2}$ & 65 & Dunkonah & Suburban \\
7 & Achimota Mall & 2015 & $14,000 \mathrm{~m}^{2}$ & 51 & Achimota: Accra & Urban \\
8 & Kumasi City Mall & N/A & $29,000 \mathrm{~m}^{2}$ & 60 & Kumasi: Asokwa & Urban \\
\hline
\end{tabular}


Shopping malls as catalyst for sub-urban development ...

the CBD of Accra Moreover, the world-class N1 (Walker Bush) highway that links the western corridor from Cape Coast, the capital of the Central Region, to Tema Harbor not only passes through the Dunkonah community but also forms the northern boundary of the West Hill's mall's property as shown in Fig. 1 which also illustrates the locations of the other Shopping Malls in Ghana.

The area of the study, Dunkonah, the community in which the West Hills Mall is situated has a population of 8,121 people, 1,932 households and 1,642 houses. The community (which is within the coordinates $5.5459^{\circ} \mathrm{N}$ and $0.3427^{\circ}$ W) is bounded to the North by the Weija township, the east by the New Bortianor township, the west by the Mile 11 township and the south by the Bortianor township as shown in the aerial photograph in Fig. 2. Fig. 3 shows how the West Hills Mall is sited at the relatively undeveloped area beneath the hills of Dunkonah.

\section{METHODOLOGY OF STUDY}

The study employed a mixed method of data collection including questionnaire, interviews and personal observation. For the questionnaire survey, the owners of the houses at Dunkonah or their representatives were considered. The owner or a representative of every $5^{\text {th }}$ house (of the 1,642 houses) was systematically selected for the survey. The size of the respondents amounted to 328 for the questionnaire survey. Information including demographic backgrounds (age distribution, education, income levels and ethnicity), rental values and the rate of construction of houses after the commencement of the mall was collected. The opinions of the respondents on the influence of the mall on

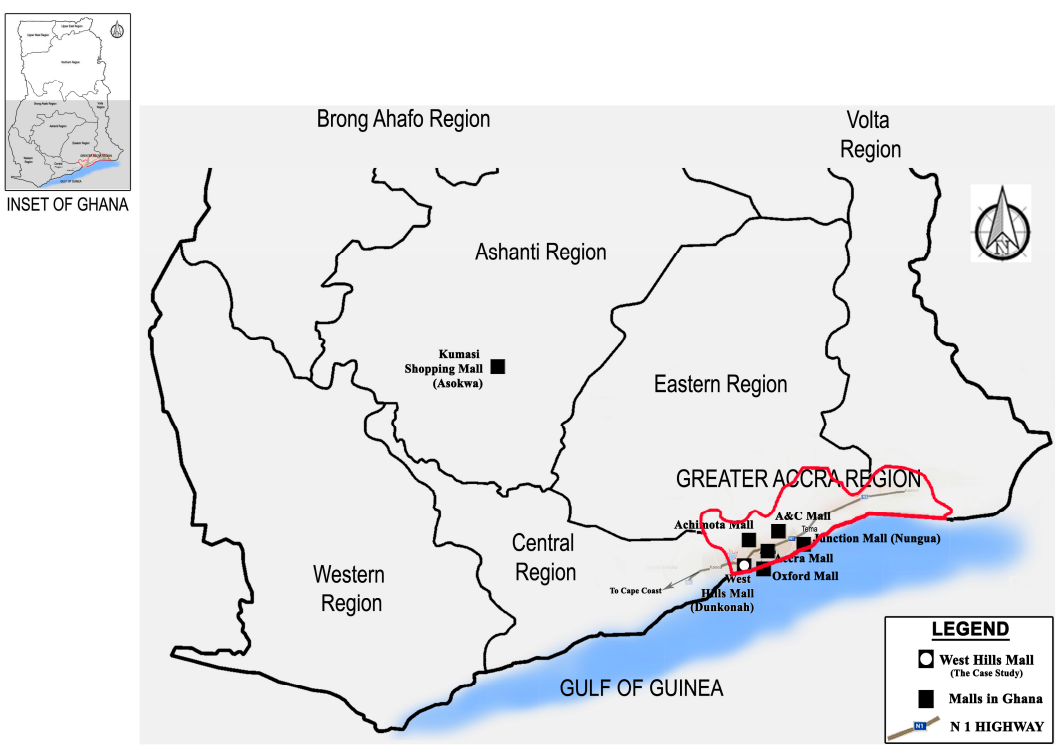

Fig.1: Southern portion of Ghana showing the study area West Hills Mall (Dunkonah) and all the other shopping malls in Ghana

(Source: Adapted and modified by authors, available at: http://commons.wikimedia.org/wiki/ File:Ghana_regions_blank.png). 


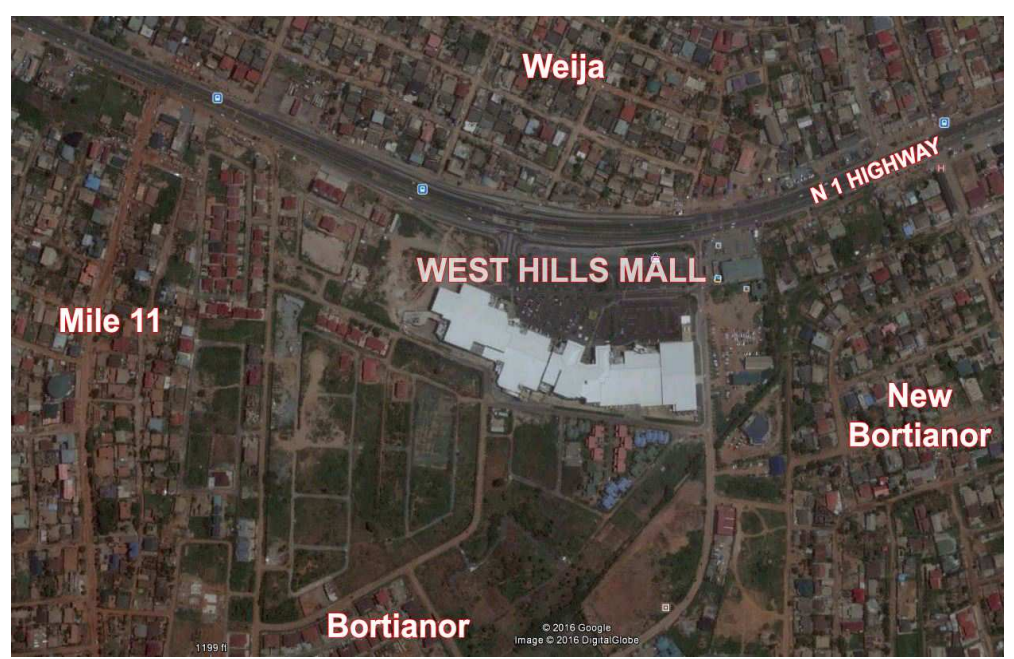

Fig. 2: Aerial view of West Hills Mall

(Source: Google Maps, 2016)

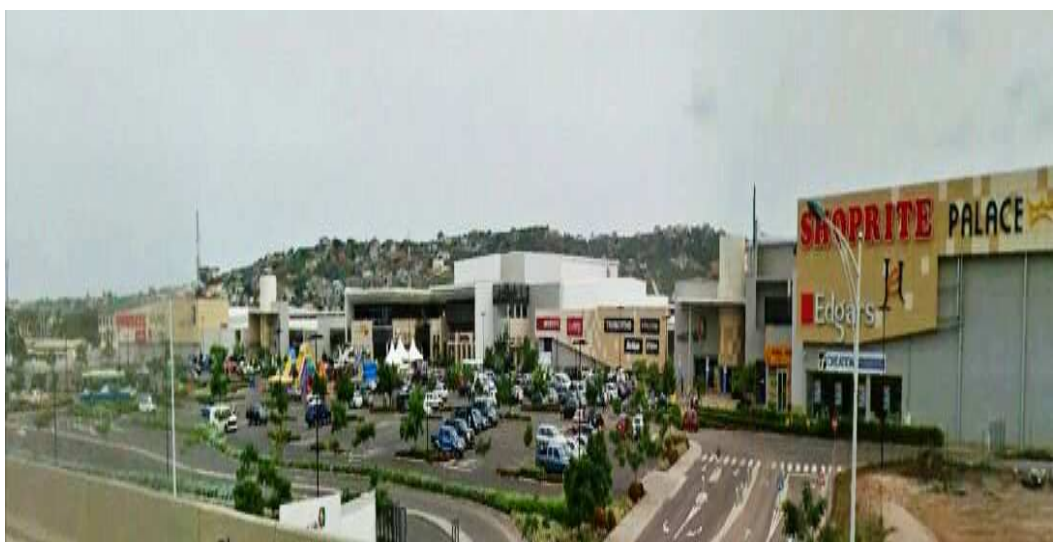

Fig. 3: View of the West Hills Mall from the N1 Highway

rate of infrastructural development, the rate and reasons for in-migration and the patronage of the mall by residents at Dunkonah were also collected with the questionnaire. Interviews were also conducted with the owners of the 11 commercial buildings that have been constructed in the community, along the MallamKasoa highway, since the opening of the mall.
Two officials each from the Ga South Municipal Assembly and the management of the West Hills Mall facility were also interviewed. The interviews also delved into the influence of the mall on development of other commercial infrastructure and other amenities at Dunkonah. Personal observation was also used to draw attention to other on-going construction works 
and activities at the study area. The survey started in May, 2016 and was finished in December, 2016.

\section{FINDINGS AND DISCUSSIONS}

The demographics of respondents

As shown in Table 2, the age group with the highest number of respondents was those between 31-40 years constituting $40 \%$, followed by those who aged between 41-50 years constituting $35 \%$, and then those between the 21-30 years $14 \%$. The two younger age groups together constituted $54 \%$ of the owners of Dunkonah houses or their representatives.

The levels of education of respondents as shown in Table 3 indicated that the house owners/representatives had a wide range of educational backgrounds. However, the majority $(45 \%)$ of the owners found in that suburban community were graduates. This group was followed by those with Senior High School and Vocational/Technical educational backgrounds with proportions of $25 \%$ and $23 \%$ respectively. Those with the basic educational level which usually characterized suburban communities like Dunkonah were rather the minority (only $7 \%)$.

The assessment of the income levels of the respondents focused on four categories, namely those whose monthly salaries ranged between 100-500, 501-1000, 1001-2000 and above 2000 Ghana Cedis as indicated in Table 4. The data implied an unevenly distributed level of income among the residents of Dunkonah which is comparable to the salaries received in the cities. The income levels of the present population at the study area are higher than the general income levels of other suburban areas in Ghana (GSS, 2008) with as much as $38 \%$ receiving more than Gh $\varnothing 2000$ monthly. The data suggest the presence of higher income earners at the study area that might also explain the presence of many professionals. The ethnic distribution of the respondents is akin to that of the Greater

Table 2: Age distribution of respondents

\begin{tabular}{llcc}
\hline No. & Age Group & Frequency & Percentage \% \\
\hline 1 & $21-30$ & 46 & 14 \\
2 & $31-40$ & 131 & 40 \\
3 & $41-50$ & 115 & 35 \\
4 & $51-60$ & 33 & 10 \\
5 & $61^{+}$ & 3 & 1 \\
& Total & $\mathbf{3 2 8}$ & $\mathbf{1 0 0}$ \\
\hline
\end{tabular}

Table 3: Levels of education of respondents

\begin{tabular}{llcc}
\hline No. & Level of Education & Frequency & Percentage \% \\
\hline 1 & Basic (Primary and Junior High) & 23 & 7 \\
2 & Senior High School & 82 & 25 \\
3 & Vocational /Technical & 75 & 23 \\
4 & University & 148 & 45 \\
& Total & $\mathbf{3 2 8}$ & $\mathbf{1 0 0}$ \\
\hline
\end{tabular}


Accra Region as revealed in the 2010 population census (GSS, 2012) with the Akan as the majority $(45 \%)$ and followed by the $\mathrm{Ga}$ Dangme with $34 \%$ as indicated in Table 5.

The rate of increase in residential rental values

The assessment of the residential rental values at the study area was based on the accommodation type, namely Single room (ensuite), Chamber and Hall, 2-Bedrooms, 3-Bedrooms and 4Bedrooms apartments as shown in Table 6 with their average rental values. The assessment was done for two different year periods: from 2009 to 2012 and 2012 to 2015 . These reflected the rent values of the period before the construction of the mall and the period during the construction of the mall through to its commissioning and operation until December 2015. The results imply that the rental values have increased after the construction of the mall.
To assess the annual percentage increase for the various categories, the means for the two periods were calculated and presented in Table 7. The data revealed that, with the exception of the values for 4-Bedroom accommodations, all the other categories experienced a considerable percentage increase within the two periods of assessments. Higher rates of increase were realized between 2011 and 2012, which coincides with the commencement of the construction of the mall. The increase may be attributed to the rush for accommodation at the mall's vicinity. The rental values for each accommodation type appreciated within all the periods. However, the 'Chamber and Hall' and 'Single Room' types realized the highest increase over the two periods. The average percentage increase for the entire period of both 2009-2012 and 2012-2014 were $28.8 \%$ and $21.3 \%$, respectively. This indicates that the rental values for the residential buildings in the period of 2009-2012 realized

Table 4: Income distribution for respondents

\begin{tabular}{clrc}
\hline No. & \multicolumn{1}{c}{$\begin{array}{c}\text { Income level per month } \\
(\text { Ghe })\end{array}$} & No. & Respondents \\
\hline 1 & $100-500$ & 39 & \% \\
2 & $501-1000$ & 89 & 12 \\
3 & $1001-2000$ & 75 & 27 \\
4 & $2000^{+}$ & 125 & 38 \\
& Total & $\mathbf{3 2 8}$ & $\mathbf{1 0 0}$ \\
\hline
\end{tabular}

Table 5: Ethnicity of respondents

\begin{tabular}{clcc}
\hline No. & Ethnic Group & Frequency & Percentage \% \\
\hline 1 & Akan & 148 & 45 \\
2 & Ga-Dangme & 111 & 34 \\
3 & Ewe & 23 & 7 \\
4 & Mole-Dagbani & 10 & 3 \\
5 & Guan & 10 & 3 \\
6 & Non-Ghanaian & 26 & 8 \\
& Total & $\mathbf{3 2 8}$ & $\mathbf{1 0 0}$ \\
\hline
\end{tabular}




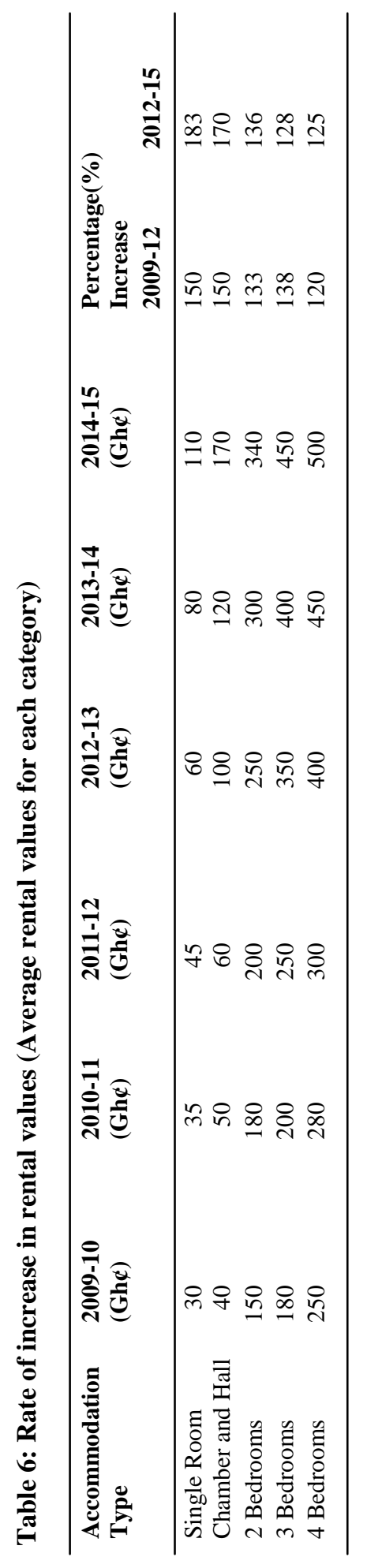

Shopping malls as catalyst for sub-urban development ... 91

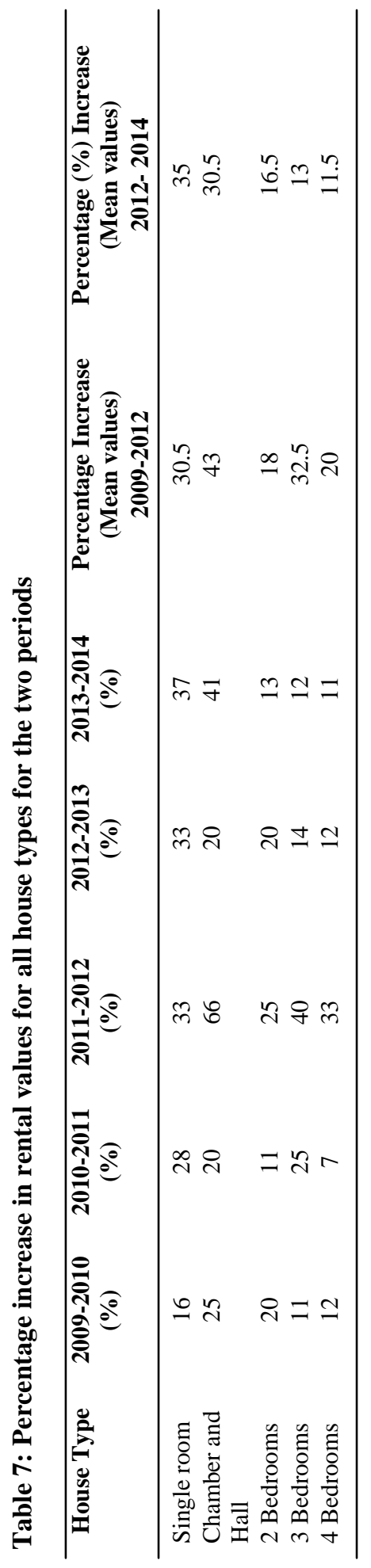

Journal of Science and Technology $\odot$ KNUST December 2016 


\section{Quagraine et al.}

the highest appreciation.

\section{Rate of infrastructure development}

The analysis of the data collected indicated that the mall has served as a pull factor attracting reasonable developments to the Dunkonah community including housing development, commercial facilities' development and an under-pass and real estate developments. Table 8 indicates the number of houses built by respondents before and after the beginning of the construction of the mall in 2012.

Before the construction of the mall in 2012, $61.3 \%(52.1 \%$ and $9.2 \%)$ of the houses of the respondents had been built. Within the period of 3 years (from 2012 through 2013 to 2014), during which the mall was constructed and commissioned for operation, as much as $28 \%$ (92 houses) were added to the existing stock. The following year, in 2015, 10.7\% (35 houses) were also added. The reasons provided for the construction of the added houses $(38.7 \%)$ at the Dunkonah community are shown in Table 9 . The respondents who were directly attracted by the presence of the mall to construct houses at the study area amounted to $37 \%$, whereas the owners who took advantage of the perceived presence of a pool of potential tenants due to the location of mall amounted to $29.1 \%$. These might explain the registration of the higher average percentage increase in rental values between 2012 and 2014 as discussed above. Other reasons given included the availability of land for purchase and the availability of family land with proportions of $12.6 \%$ and $11 \%$ respectively.

The study revealed that there were the construction of 11 commercial buildings to house banks, shops, restaurants and pubs between 2012 and 2015 in the study area.

Table 8: Year of construction of houses

\begin{tabular}{cccc}
\hline No. & Period of construction & No. of houses & Percentage\% \\
\hline 1 & Before 2011 & 171 & 52.1 \\
2 & 2011 & 30 & 9.2 \\
3 & 2012 & 22 & 6.7 \\
4 & 2013 & 39 & 11.9 \\
5 & 2014 & 31 & 9.4 \\
6 & 2015 & 35 & 10.7 \\
& Total & $\mathbf{3 2 8}$ & $\mathbf{1 0 0 . 0}$ \\
\hline
\end{tabular}

Table 9: Reasons for construction of houses

\begin{tabular}{|c|c|c|c|}
\hline No. & Reasons for house construction & No. of respondents & Percentage \% \\
\hline 1 & Availability of family land & 14 & 11.0 \\
\hline 2 & Availability of land to purchase & 16 & 12.6 \\
\hline 3 & Availability of potential tenents for housing & 37 & 29.1 \\
\hline 4 & Closeness to the mall & 47 & 37.0 \\
\hline \multirow[t]{2}{*}{5} & Building at the outkirts of Accra CBD & 13 & 10.3 \\
\hline & Total & 127 & 100.0 \\
\hline
\end{tabular}


These were mainly located along the mall side of the N1 highway. Out of the 11 commercial facility owners interviewed, seven claimed they decided to construct and operate their commercial facilities at the study area to take advantage of the presence of the mall. The other four, however, had already planned on undertaking the projects before works began for the construction of the mall.

Although the main Mallam-Kasoa highway (portion of the N1 highway that boarded the northern part of the mall) had been constructed before the construction of the mall started, the interviews revealed stakeholders' realization of the need for a strategy that would help prevent road traffic congestion at the mall intersection and enhance efficient flow of traffic to and from the mall. An interchange/underpass was thus constructed by the owners of the mall. Thus the main road infrastructure project that was occasioned by the location of the mall is the interchange/underpass project. The access roads to the neighbouring communities, however still remain untarred. It was observed that additional houses were still under construction, which would add to the pool of houses constructed since the construction and operation of the West Hills Mall.

Real estate development has also increased since the beginning of the construction of the mall, and notable among them is the Fortune City development. Fig. 4 shows the proposed designs of the development whereas Fig. 5 is an illustration of some of the buildings under construction in the first phase, code-named Diamond Villa. The Fortune City project which is located between 700 and 800 metres from the mall occupies a 150 acre land and it is mainly devoted to residential development including apartments, detached and semi-detached houses and community centers with tennis courts, bars, restaurants, gymnasium and pools.

\section{Rate and reasons for migration}

The results of the assessment of the rate and reasons for migrating into the Dunkonah suburb are also discussed below. As shown in Table $10,54.9 \%$ of respondents were already residents at Dunkonah before the construction of mall started in 2012. Thus, the migrants to the

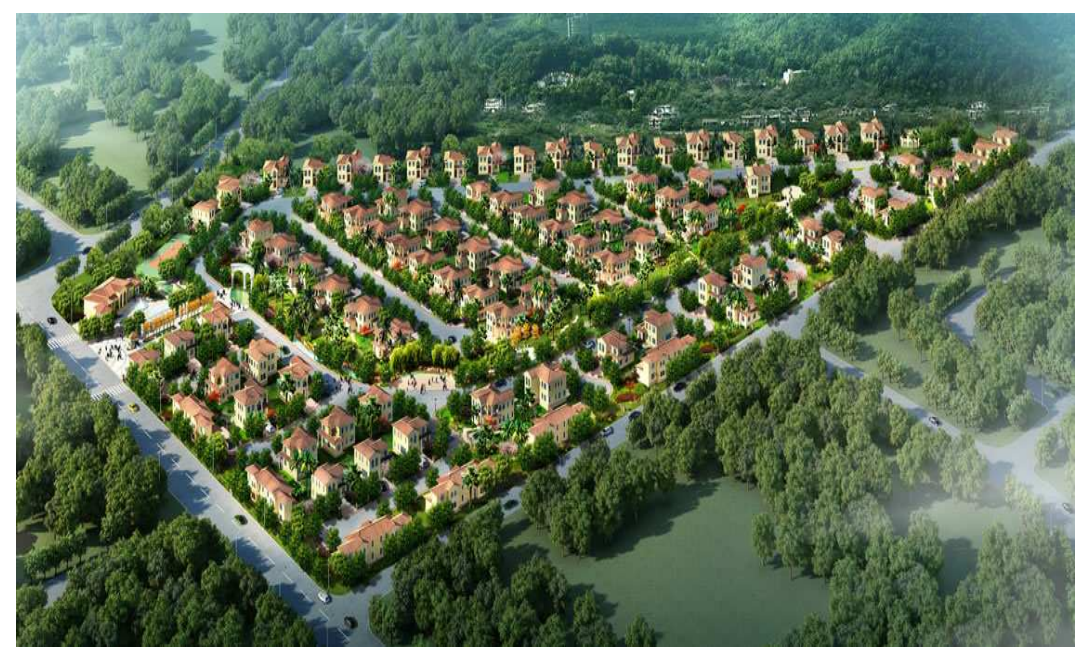

Fig. 4: Picture of the proposed design of Fortune City real estate developments (Source: Fortune City, 2015 


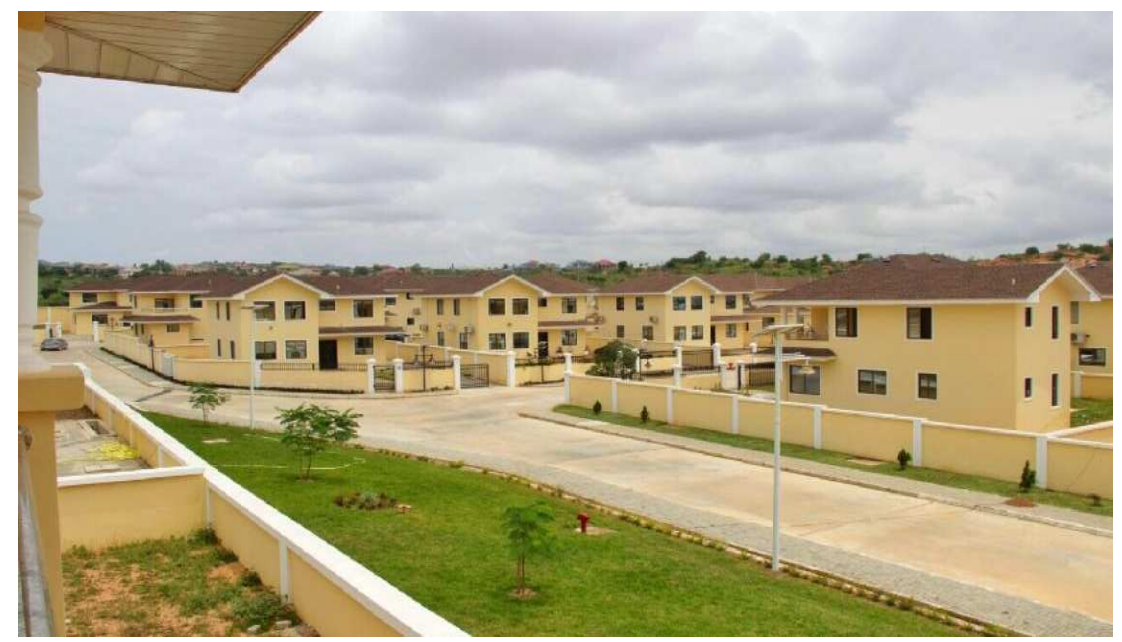

Fig. 5: View of some of the buildings of Fortune City's Diamond Villa development (Source: Fortune City, 2015)

Table 10: Rate of migration to Dunkonah

\begin{tabular}{|c|c|c|c|}
\hline No. & Year/Period & No. of respondents & Percentage \% \\
\hline 1 & Before 2012 & 180 & 54.9 \\
\hline 2 & 2012 & 33 & 10.0 \\
\hline 3 & 2013 & 41 & 12.6 \\
\hline 4 & 2014 & 36 & 10.8 \\
\hline \multirow[t]{2}{*}{5} & 2015 & 38 & 11.7 \\
\hline & Total & 328 & 100.0 \\
\hline
\end{tabular}

area since the beginning of the construction of mall until 2015 (within a period of 4 years) constituted $45.1 \%$. Thus, the population of Dunkonah can be said to have increased from 8,121 to 11,784 and that of the entire Bortianor neighborhood in which Dunkonah is situated from 32,485 to 47,136 .

The year that registered the highest migration was 2013 (12.6\%), followed by 2015 (11.7\%) and 2014 at $10.7 \%$ and then 2012 at $10 \%$. The cumulative increase in migration to the Dunkonah area from 2012 to 2015 is also illustrated in
Fig. 6.

The reasons provided by the $45.1 \%$ (148) of the respondents for their migration varies considerably as listed in Table 11. The majority of the respondents $(29.8 \%)$ migrated to get closer to their work places at Dunkonah, whereas $24.3 \%$ and $16.2 \%$ migrated to find residential accommodation and to occupy staff accommodation respectively. Thus, $40.5 \%$ of the migration was due to the residential accommodation that was developing at the vicinity of the mall. Whereas $16.2 \%$ of the respondents actually moved away 
Shopping malls as catalyst for sub-urban development ... 95

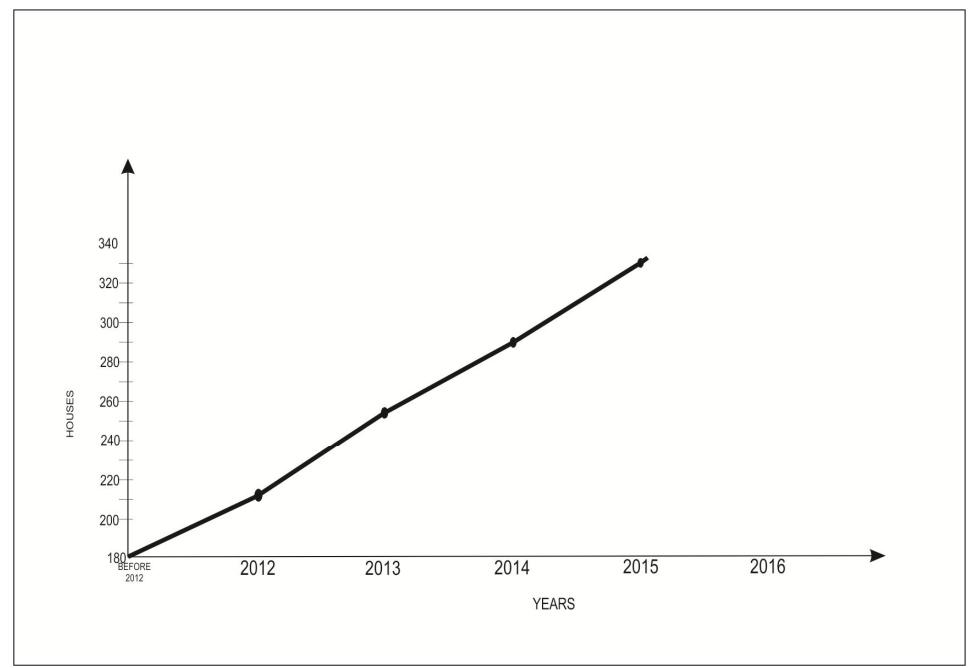

Fig. 6: Cumulative increase of migrants to Dunkonah, site of West Hills Mall

Table 11: Reasons for migration

\begin{tabular}{clcc}
\hline No. & Reasons for migration & No. of respondents & Percentage\% \\
\hline 1 & To occupy staff accommodation & 24 & 16.2 \\
2 & Only location for residential accommodation & 36 & 24.3 \\
3 & Nearness to place of work & 44 & 29.8 \\
4 & To move away from stress in the CBD & 24 & 16.2 \\
5 & To live in close proximity to the mall & 20 & 13.5 \\
& Total & $\mathbf{1 4 8}$ & $\mathbf{1 0 0 . 0}$ \\
\hline
\end{tabular}

from the stressful life in the CBD of Accra to settle in the Dunkonah suburb, the mall directly served as pull factor to $13.5 \%$ of the respondents who moved just to get closer to the new mall.

Regardless of the increase in migration into the Dunkonah community, quite a number of the population also frequented the CBD of Accra as presented in Table 12. Out of the 328 respondents, $16.2 \%$ still travelled to the CBD of Accra on a monthly basis, $43.9 \%$ on weekly basis, $7.9 \%$ on daily basis and $32 \%$ occasionally. All of these visits were necessary because most of their required corporate services were provided only at the CBD. This further implies that all the respondents still frequented to the CBD to add up to the congestion phenomenon in the city of Accra.

\section{Patronage of shopping mall by residents}

The reasons given by the respondents for shopping mall visits as shown in Table 13 affirm the fact that the facility is actually serving as a community center that provides spaces for social interactions, congregations and the supply of various types of needs to stabilize the population as confirmed by Consumer Reports 
Table 12: Frequency of travel to the city centre

\begin{tabular}{clrr}
\hline No. & Frequency of travel & Frequency & Percentage \% \\
\hline 1 & Monthly & 53 & 16.2 \\
2 & Weekly & 144 & 43.9 \\
3 & Daily & 26 & 7.9 \\
4 & Occasionally & 105 & 32.0 \\
& Total & $\mathbf{3 2 8}$ & $\mathbf{1 0 0 . 0}$ \\
\hline
\end{tabular}

Table 13: Purpose for visiting the mall

\begin{tabular}{llcc}
\hline No. & Purpose & No. of respondents & Percentage \% \\
\hline 1 & Mostly for work & 49 & 14.9 \\
2 & Mostly for purchases & 92 & 28.0 \\
3 & Mostly for business transactions & 75 & 22.9 \\
4 & Mostly for window-shopping, hanging around, & 112 & 34.2 \\
& socializing and to relaxing. & $\mathbf{3 2 8}$ & $\mathbf{1 0 0 . 0}$ \\
\hline
\end{tabular}

(1986). Whereas $14.9 \%$ of the respondents worked in the mall, $28 \%$ and $22.9 \%$ went to the mall to purchase and to transact other businesses respectively. It must be noted that as much as $34.2 \%$ went to the facility not to buy or transact business but just to window-shop, "hang around" to meet and socialize with friends and to relax. Where people do not wish to purchase any item, the mall serves as a pull factor for socialization.

\section{CONCLUSIONS}

This study set out to find out the possibility of the Shopping Mall acting as a catalyst to suburbanization. The study revealed that the presence of the mall directly or indirectly influenced the migration of $45.1 \%$ of the respondents who were mostly young, highly educated and higher income earners who could bear the rising rental values at their destination, the Dunkonah suburb. It must be noted that $54.9 \%$ of the respondents were already living there before the construction of the mall. Whereas $13.5 \%$ of those who migrated were directly influenced by the mall and its location, the remaining $86.5 \%$ seemed to be indirectly influenced by the mall as its presence occasioned the provision of accommodation and jobs at the study area.

Considering the high percentage $(34.2 \%)$ of residents who go to the mall for socialization, window-shopping and relaxation, it is reasonable to conclude that the mall has succeeded in serving as a community center to the residents of Dunkonah. Nevertheless, most of the residents of Dunkonah continue to visit the CBD of Accra for other needs (either on daily, weekly or monthly basis) probably not catered for by the mall. Only $32 \%$ of the respondents did not frequent the CBD of Accra but went there only on occasions.

Though the housing stock of the area also in- 
Shopping malls as catalyst for sub-urban development ... 97

creased by $38.7 \%$ from the beginning of the construction of the mall in 2012 until December of 2015, the reasons given were mostly indirectly related to the presence of the mall. Nevertheless, the movement of as many as 37\% of them was directly attributed to the presence of the mall. Moreover, $63.6 \%$ of the 11 commercial buildings' owners claimed that the presence of the mall directly influenced their decisions for the development. The presence of the mall has also occasioned other infrastructural developments including real estate developments and an improvement in the already existing N1 highway to ease traffic flow.

The findings of this study seemed to support the fact that shopping malls can be employed as catalyst for the development of suburban communities in Ghana. However, Shopping Mall development has to be holistic to include the prevention of suburban residents from traveling to the city. As more people are pulled by malls to reside and work at the suburban communities, most needs are acknowledged, considered and provided for by the government. This paper notes that, population densities influence decisions of governments on infrastructural development, which according to UNDP (2013) ultimately leads to suburban development and consequently reduced suburban/rural-urban migration and the congestion of cities. Further studies must be concentrated on the impact of shopping malls on the development of the conventional Ghanaian market as a commercial/sociocultural facility in the urban context.

\section{REFERENCES}

Abaza, M. (2001). Shopping Malls, Consumer Culture and the Reshaping of Public Space in Egypt. Theory, Culture and Society 18(5): 97 $-122$

Abaza, M. (2011). Critical Commentary. Cairo's Downtown Imagined: Dubaisation or Nostalgia?. Urban Studies 48(6): 1075-1087.

Ackah, C. and Medveder, D. (2010). Internal Migration in Ghana: Determinants and Wel- fare Impacts. Policy Research Working Paper No. 5273. Washington DC: World Bank.

Anning-Dorson, T., Kastner, A. and Mahmoud, M. (2013). Investigation into mall visitation motivation and demographic idiosyncrasies in Ghana. Management Science Letters, 3(2): 367-384.

Azuliya, D. (2014). Accra's Congestion Problems will worsen if National Investment Concentration Continues: https:// www.modernghana.com/news/552610/accras -congestion-problems-will-worsen-ifnational-investme.html. Accessed on $13 / 05 / 2015$

Boamah, E. F. and Amoako, C. (2013). Regionalism and Urban Development Planning in Africa: A Collaborative Framework for Decentralized Planning in Ghana Developing. Country Studies 3(9): 142-154

Burger, M. (2014). A literature Review: Understanding the role of Shopping in Society: The 3rd International Virtual Conference. Conference of Informatics and Management Sciences.

Christaller, W. (1966). Central places in Southern Germany. Englewood Cliffs, N. J. Prentice-Hall.

Consumer Reports (1986). History of Shopping Centres: Consumers Union. New York: Consumers Union of the United States.

De Nisco, A. and Napolitano, M. A. (2006). Entertainment orientation of Italian shopping centres: antecedents and performance. Managing Service Quality. An International Journal, 16(2): 145 - 166.

Effah, E. (2014). West Hills Mall Inaugurated: http://citifmonline.com/2014/11/26/west-hills - mall-inaugurated. Accessed on $11 / 12 / 2015$ 
Farrag, D. A., El-Sayed, I. M. and Belk, R. M (2010). Mall Shopping Motives and Activities: A Multimethod Approach. Journal of International Consumer Marketing 22: 95115

Fortune City (2015). Fortune City Real Estate Development. http://fortunecity.com.gh.cp50.webhostbox.net/. Accessed on 20/05/2016

Ghana Business News (2017). \$135m Accra traffic project takes-off March 2013. https:// www.ghanabusinessnews.com/2013/02/10/1 $35 \mathrm{~m}$-accra-traffic-project-takes-off-march2013/. Accessed on 13/01/2017

Ghana Statistical Service (GSS). (2005). Population Data Analysis Reports, Vol. 1: Socioeconomic and Demographic Trends Analysis. Ghana Statistical Service, Accra.

Ghana Statistical Service (GSS). (2008). Ghana Living Standards Survey Report of the Fifth Round (GLSS 5). Ghana Statistical Service, Accra

Ghana Statistical Service (GSS). (2012). 2010 Population and Housing Census: Summary Report of Final Results, GSS. Sakoa Press, Accra

Ghana Statistical Service (2014). 2010 Population and Housing Census: District Analytical Report, Ga South Municipality. Ghana Statistical Service.

Google Maps (2016). https:// w w w. g o o g $1 \mathrm{e}$. c o m . g h / webhp.Accessed:08/05/2016.

Grove, D. and Huszar, L. (1964). The Towns of Ghana: the Role of Service Centres in Regional Planning. The University of Science and Technology, Ghana Universities Press, Accra.

Heffner, K and Twardzik, M (2014). Shopping Malls and Its Social Impact on the Outer
Metropolitan Zones. 5th Central European Conference in Regional Science - CERS, October $5^{\text {th }}-8^{\text {th }}$, Kosice, Slovak Republic

Howard, E. (1902). Garden Cities of Tomorrow. London: S. Sonnenschein Ltd.

Irazabal, C. and Chakravarty, S. (2007). Entertainment-Retail Centres in Hong Kong and Los Angeles: Trends and Lessons. International Planning Studies, 12(3): 241-271.

Ligthelm, A. (2008). The impact of shopping mall development on small township retailers. South African Journal of Economic and Management Sciences, 11(1): 37-53.

Loeb, C. and Luester, A. (2015). The Design of Frontier Spaces: Control and Ambiguity: Routelege New Edition.

Mangleburg, T. F., Donney, P. M. and Bristol, T. (2004). Shopping with Friends and teens' Susceptibility to Peer Performance. Journal of Retailing, 80: 101-116.

McGranahan, D. A. (1999). Natural Amenities Drive Rural Population Change. Food and Rural Economics Division, Economics Research Service, US Department of Agriculture. Agriculture Economic Report No. 781.

Moore, M., Gould, P. and Keary, B. S. (2003). Global Urbanization and Impact on Health. International Journal of Hygiene and Environmental Health, 206(4/5): 269-278.

Pares-Ramos, I. K., Gould, W. A. and Aide, T. M. (2008). Agricultural Abandonment, Suburban Growth, and Forest Expansion in Puerto Rico between 1991 and 2000. Ecology and Society 13(2). [online] URL: http:// www.ecologyandsociety.org/vol13/iss2/art1/. Accessed on 22/11/2015

Poku-Boasi, M. (2014). Theoretical Underpinnings of the Study: In K. K. Adarkwa, (ed.), Human Settlements and Service Delivery in 
Shopping malls as catalyst for sub-urban development ... 99

Ghana. University Printing Press (KNUST), Kumasi.

Squires, D. S. and Kubrin, C. E. (2006). Privileged Places; Race, Opportunity and Uneven Development in Urban America. Lynne Rienner Publishers.

Takyi, H., Poku, K. and Anin, E. (2013). An Assessment of Traffic Congestion and its Effect on Productivity in Urban Ghana. International Journal of Business and Social Science, 4(3): 225-234.
Thurston, L. and Yezer, A. M. J. (1994). Causality in the Suburbanization of Population and Employment. Journal of Urban Economics, 35(1): 105-118.

UNDP (2013). Human Developments Report: http://hdr.undp.org/en/2013-report. Accessed on $02 / 07 / 2016$

World Health Organization (WHO). (2001). World Health Report 2000, Health Systems: Improving performance, WHO, Geneva. 